\title{
The Real Winners in Aid for Trade: \\ An Economic Analysis
}

\author{
Timothy Wolf Barham
}

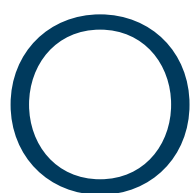

ver the past two decades, hundreds of billions of dollars have been spent on official development assistance programs to assist developing countries around the world through the Aid for Trade (AfT) initiative. Although the goal of the AfT initiative is to reduce global poverty levels, there is limited evidence that AfT actually reduces poverty. While positive economic growth linked to AfT programs can be seen in both developed and developing countries, developed countries do not experience the same downfalls of international trade as the least developed countries. This article reviews existing research on the AfT initiative, the winners and losers of such agreements, and the potential policy vehicles that can be used by participating governments and organizations to mitigate the unintended effects of AfT. 
Developing countries face many direct and indirect challenges that hinder their access to global trade markets. The problems range from a lack of physical infrastructure necessary for supplying goods to unfavorable regulatory environments. With the ultimate goal of alleviating poverty, the Aid for Trade (AfT) initiative within official development assistance programs was designed to assist developing countries integrate into the world economy by encouraging international trade (WTO 2019a). In cooperation with numerous intergovernmental organizations (IGOs) and development banks, AfT programs cover a complex range of activities, including providing technical assistance to help countries develop trade strategies, infrastructure development through trade-related infrastructure, and productive capacity so that developing countries can focus on comparative advantages and diversify exports (Gero 2014). However, while the AfT initiative may improve access to international markets for participating developing countries, there is limited evidence that AfT programs actually reduce poverty despite the growth in aid.

While the least developed countries (LDCs) who receive AfT programs may experience improved economic outcomes, the real winners from trade may be the participating developed countries. More than a decade after the inception of AfT, stakeholders and scholars wonder if donor-funded trade programs are effectively building the capacity in LDCs to enhance trade flows, integrate these countries into the global trading system, and achieve the ultimate goal of reducing poverty (Gnangnon 2018).

This paper begins with an overview of foreign aid, trade and development assistance, and the purpose and intended benefits of AfT. It then presents an analysis of potential unanticipated effects of the programs and discusses the winners and losers of AfT. The paper concludes with an assessment of the initiative, policy implications, and recommendations to participating governments and organizations.

\section{BACKGROUND AND PURPOSE OF THE AID FOR TRADE INITIATIVE}

During the 2017 Aid for Trade Global Review at the World Trade Organization (WTO), the Secretary-General of the Organization for Economic Co-operation and Development (OECD) José Ángel Gurría said, “...trade is not responsible for the world’s evils, neither is it possible for trade to resolve all the world's problems" (WTO 2017). While trade certainly cannot be held responsible for all the problems developing countries face in spurring economic growth and reducing poverty, many studies examine both the positive and negative effects that may come with using international trade as a tool to help developing countries (Suwa-Eisenmann and Verdier 2007; Hoekman and Olarreaga 2008). Before AfT initiatives, the activities of aid and trade were largely separate (Suwa-Eisenmann and Verdier 2007). AfT programs were the first collaboration between the international trade and international development communities intended to encourage sustainable economic growth in developing countries, using trade as a mechanism to lift people out of poverty (Suwa-Eisenmann and Verdier 2007).

AfT programs were created to provide LDCs with financial and technical assistance to develop trade. For the purpose of AfT, the WTO defines LDCs based on the United 
Nations designation of the 47 least-developed countries (WTO 2019b). Specifically, LDCs must have a Gross National Income (GNI) per capita of US\$1,025 or below along with other criteria signaling economic vulnerability (UN 2019). The WTO gives special favor and flexibility to LDCs because these countries are especially susceptible to destabilizing economic shocks. More advantaged WTO members are expected to use extra effort to be flexible with LDCs in trade agreements, through actions such as lowering import barriers on LDC exports (WTO, n.d.). Despite potential benefits from trade, many developing countries and LDCs cannot participate in the global market due to barriers to entry, such as limited trade infrastructure (Hoekman and Olarreaga 2008). To address this, AfT programs are designed to assist developing countries and LDCs in building up supply-side capacities so that they are better prepared to export their goods and realize potential benefits through global trade.

At the 2001 Doha Development Round trade negotiations, WTO member countries discussed the shortcomings of traditional trade liberalization policy in regard to development within poorer countries. Participants at the forum in Doha examined issues in export markets for developing countries, including tariff and non-tariff export barriers, as well as lack of infrastructure, insufficient financing, and technological ability (Bouët et al. 2005). Trade ministers at the WTO Hong Kong Ministerial Conference instituted the AfT initiative in 2005 to assist with addressing such constraints. While the WTO has negotiated AfT initiatives at multiple conferences since 2001, there is still limited agreement on trade liberalization policies and the effectiveness of AfT activities (Gnangnon 2018).

In 2006, following the Hong Kong negotiations, the WTO created a Task Force with the goal of identifying and responding to the needs of recipient countries to develop relevant AfT programs (WTO 2019a). The most recent OECD figures show AfT programs received US $\$ 410$ billion between 2006 and 2017, with the largest proportions going to countries in Asia and Africa at US\$154.9 billion and US\$146.2 billion, respectively. As of 2019, participants funded 178,141 AfT projects, at an average of US $\$ 2.25$ million per project (OECD and WTO 2019).

To achieve the goals of the AfT initiative, the WTO focuses on four main areas: trade policy and regulation, economicinfrastructure, productive capacity building, and adjustment assistance. Trade policy and regulation refers to assisting recipient countries to develop policy and agreements with countries in the developed world. Economic infrastructure assistance provides money for countries to invest in the physical infrastructure needed to enter the global trading market. Productive capacity building refers to donor-funded assistance to improve products and support competitive producers to export goods. Lastly, adjustment assistance helps recipient countries manage costs associated with trade liberalization, such as unemployment or lowered incomes compared to protected trade conditions (Jomo and Von Arnim 2008). To administer these services, the WTO partners with dozens of IGOs and development banks around the world that then work directly with recipient countries (WTO 2019a). The developed countries that provide AfT assistance receive preferential treatment in trade and receive reduced trading barriers in recipient countries in exchange for their assistance. 


\section{ANALYSIS OF THE EFFECTS OF AID FOR TRADE}

Economic assessment of the effects of the AfT initiative on both economic growth and poverty reduction, such as the analyses conducted by OECD (OECD and WTO 2019) and the 2006 WTO Task Force, is necessary to test the extent to which AfT programs are producing the intended outcomes. Along with the Task Force, which helps operationalize AfT, the WTO also created a monitoring body that reviews global effects of AfT (WTO 2019a). Estimates of the economic impact of AfT on poverty reduction are difficult to measure; many evaluations of the results of AfT are based on causal assumptions about the impact of AfT programs on poverty alleviation (Gero 2014). AfT is targeted to assist LDCs, but its activities do not affect all LDCs in the same manner. Evidence shows that poorer LDCs may experience more economic growth from AfT trade policies than wealthier LDCs (Gnangnon 2018). Regardless of relative wealth, AfT programs are designed to build trade capacity at a country-wide, macro-scale level. To measure the economic impact of AfT programs, one needs to examine the effects of the initiative at two levels: the winners and losers from AfT and the unintended effects of AfT on LDC populations.

\section{WINNERS AND LOSERS IN INTERNATIONAL AID AND TRADE}

For international trade to occur the agreement must be mutually beneficial-but it is not required that these benefits are distributed equally. While recent surveys show that economists tend to favor international trade with regard to aiding LDCs (Wolla and Esenther 2017), some development experts argue that trade liberalization disproportionately serves the interests of wealthy countries and increases disparities in the poorest countries (Jomo and Von Arnim 2008; Anderson and Martin 2005). Studies have shown as countries have moved to higher income level classifications, such as from LDC to developing country, inequality has risen, but countries that did not move classifications have experienced declining income inequality rates (UNDP 2013). Therefore, while trade liberalization may increase inequalities in some LDCs, these countries should still see economic growth from AfT. These conflicting trends show why analyzing AfT winners and losers is critical to ensure that the poorest countries always benefit in trade agreements.

The most obvious winners from AfT are the developed countries that benefit from preferential trade with LDCs. LDCs participating in AfT initiatives lower tariffs on incoming goods from assisting developed countries. While lower tariffs allow consumers in LDCs to receive cheaper products, they greatly benefit domestic firms in developed countries.

Developed countries further benefit from having LDCs as new trade partners through the increased variety and low prices of imports. LDCs are often able to produce goods at a lower cost than domestic producers in developed countries, allowing them to compete with pricing in developed countries and potentially drive down prices (Wolla and Esenther 2017). Lower prices increase consumers' purchasing power, allowing them to consume more at a higher utility, improving overall economic welfare.

Additionally, with reduced tariffs and trade preference, producers in developed countries are able to sell cheaper versions of their goods to new consumers in LDCs, increasing overall 
trade levels. Increased trade may incentivize consumers in LDCs with both investment and innovation effects; introducing new products into the market spurs new competition, thus encouraging further economic growth. These indirect effects are hard to measure and while many studies track investment and innovation effects, there has been little research specific to AfT (Hoekman and Olarreaga 2008).

There is sufficient evidence that many recipient countries are able to build their capacity to trade globally by utilizing AfT funds (Bearce et al. 2013), showing that LDCs can be considered winners as well. However, conflicting with the original intent of AfT, there is evidence that recipient countries' benefits are not proportional to those enjoyed by the developed countries providing aid. The models used to estimate AfT benefits are based on assumptions that do not consider labor displacement, economic downturn, or debt, so expected recipient countries' benefits will not be as great as predicted (Jomo and Von Arnim 2008).

The first evident losers in LDCs are third parties not directly benefiting from increased global trade, such as domestic firms and small businesses that cannot compete with global pricing and economies of scale. These firms are forced to either leave the market or reduce prices to meet the demands of consumers (Wolla and Esenther 2017). The loss of firms and individuals who are unable to compete in the market limits overall economic growth.

In addition to prices, as LDCs become more open to international business opportunities through trade liberalization, sheer volume of goods becomes a problem for smaller domestic firms. Despite AfT assistance, domestic competitors may be incapable of adjusting production capabilities to match or exceed the capacities of larger-scale foreign firms. While a portion of AfT funding is targeted to adjustment assistance for local domestic firms, the allocated funds likely cannot cover all required adjustments related to trade liberalization in recipient countries (Gnangnon 2018).

One study shows as countries receive larger amounts of foreign aid, full liberalization progresses at a quicker rate (Borgatti 2007). As countries experience this rapid change, it becomes harder for IGO adjustment programs to keep up with and fully address the unintended effects of liberalization. LDCs will experience certain benefits from participating in AfT, but it is important to evaluate the negative aspects in order to consider how these effects may be remedied to better assist all parties in LDCs.

\section{UNINTENDED NEGATIVE EFFECTS}

While AfT is primarily used to improve trade conditions in poor countries, there are three main inadvertent results of trade that may outweigh the benefits of participating in AfT for recipient countries: trade liberalization, "Dutch disease," and aid fungibility.

\section{TRADE LIBERALIZATION}

Trade liberalization in recipient countries is a key effect of AfT, with both positive and negative associated aspects. Some scholars argue that trade liberalization provides net global benefits, while others argue that it unfairly harms developing countries (Bearce et al. 2013; 
Gnangnon 2018; Jomo and Von Arnim 2008). Trade liberalization may lead to unemployment and lower incomes in internationally uncompetitive countries, potentially resulting in net welfare loss as developed countries reap initial benefits of trade liberalization (Jomo and Von Arnim 2008). Proponents of trade liberalization disagree with this perspective, arguing that developing countries receive substantial economic gains of their own from complete trade liberalization (Anderson and Martin 2005).

The World Bank Group recognized the problems associated with liberalization and created a statistical model to assess the issue, examining the impact of full trade liberalization through AfT programs over the first decade of the AfT initiative. Specifically, the goal of the model was to determine the likelihood of reducing the number of people living on less than US\$1 per day from 622 million to 32 million (Anderson and Martin 2005). While the original model showed promising results, with a five percent reduction in poverty, the parameters of the statistical model were adjusted over the years and showed that in AfT's current form, more than 70 percent of AfT benefits accrued to rich countries (Jomo and Von Arnim 2008). Other World Bank models of trade liberalization scenarios show outcomes with even greater discrepancies between wealthier countries and LDCs, with gains up to US $\$ 80$ billion for donors and accounting for 82 percent of the potential gains from trade in 2015 (Jomo and Von Arnim 2008). Another statistical model that focused on AfT initiatives specific to the agriculture sector showed that under certain trade liberalization scenarios, recipient countries could actually lose US\$3 billion overall while wealthy countries gain US $\$ 19$ billion (Bouët et al. 2005). These models further show that while donor and recipient countries may both win, developed countries win more.

Alternatively, models developed by proponents of AfT show greater benefits for recipient countries through US AfT programs, with one model predicting that a US $\$ 1$ increase in total US AfT funds would be associated with a US\$69 increase in a recipient country's exports two years later (Bearce et al. 2013).

As illustrated above, potential trade liberalization effects vary based on the models that are created to predict outcomes; scholars argue that model estimates such as these differ when benefits are overestimated, and costs of free trade are neglected (Jomo and Von Arnim 2008). With discrepancies between the estimates of the economic gains from AfT across different models, it is difficult to make an accurate assessment of the effects of trade liberalization on recipient countries.

\section{"DUTCH DISEASE"}

"Dutch disease" is defined as the negative situation that arises after foreign aid is used to purchase local non-tradable goods and services, like utilities or public transportation, instead of exportable or importable goods and services (Adam 2005). The phenomenon occurs when the success of one sector in the economy ultimately harms the broader economy, specifically exports. Given that improving export capacities in recipient countries is an important component of AfT initiatives, the "Dutch disease" effect is problematic.

In practice, when foreign aid from AfT is invested to build up the non-tradable goods and services sector, there will be a price change in non-tradable sectors and an appreciation of exchange rates in domestic currency while prices in the tradable sectors of the recipient 
country remain fixed at world prices. This price change specific to the non-tradable sector will be reflected through increased consumer demand for imported goods that are now comparatively cheaper than locally available domestic products. This change in demand could further cause an appreciation in exchange rates, exacerbating the increase in domestic prices compared to foreign products. In short, the quantity of imported goods purchased will initially increase in AfT recipient countries, with an eventual decrease in exports as tradable goods appear more expensive in the global trade markets (Suwa-Eisenmann and Verdier 2007). The resulting loss of competition for exports could damage the private sector in AfT recipient countries, further heightening issues of inequality.

"Dutch disease" problems in private sector competitiveness could be alleviated through additional donor aid. However, the provision of new funds could then lead a country towards aid dependency (Suwa-Eisenmann and Verdier 2007).

Supporters of AfT counter the potential for "Dutch disease" by stating that the internal characteristics of targeted LDCs reduce the probability of these negative effects occurring; they argue that LDCs might actually benefit from an appreciation of exchange rates due to the low substitutability between domestic production of goods and imported goods. Additionally, the income effect from foreign aid may not lead to "Dutch disease," as the tradable and nontradable sectors may both rise together (Suwa-Eisenmann and Verdier 2007). If AfT builds up trade infrastructure and supply-side capacities of recipient countries, it could offset the rise in demand within LDCs for cheaper foreign goods that increases domestic prices, reducing the likelihood of any "Dutch disease" problems (Bearce et al. 2013).

\section{AID FUNGIBILITY}

Critics call attention to aid fungibility as another potential negative effect of AfT. Aid fungibility refers to the action of moving funds into other forms of foreign aid and then spending the funding in ways not originally intended by donors (Gnangnon 2018). Traditional foreign aid is often fungible; traditional aid funds may substitute for spending that recipients would have undertaken regardless, such as in education, thereby allowing the recipient to use additional funding for other purposes, such as in defense (Feyzioglu et al. 1998). While AfT funds used in unintended ways may still stimulate economic growth and encourage further investment, the initiatives may not address the poverty reduction measures and programs they were originally created to implement. While scholars have written on the fungibility of traditional aid to LDCs, there is no present research on the fungibility of AfT (Feyzioglu et al. 1998; Bearce et al. 2013).

Proponents argue that it is unlikely that AfT would be as fungible as other forms of foreign aid and may even have positive effects for recipient countries. Spending AfT funds for purposes other than originally intended may induce export promotion and actually encourage further economic activity in recipient countries (Bearce et al. 2013). If the funds succeed in developing competitive export industries, AfT aid fungibility may encourage recipient governments to reduce trade barriers and comply with liberalized global trade policy (Bearce et al. 2013). Additionally, AfT is specifically channeled to a small set of trade development projects that LDCs would be unable to address on their own without foreign funding and expertise, most especially to the transportation and communication sectors, which are not fungible (Feyzioglu et al. 1998). If recipient countries did attempt to use AfT 
to fund additional projects not originally in the budget, this would not free up other funds in the same way as traditional aid (Bearce et al. 2013).

\section{ASSESSMENT AND POTENTIAL POLICY}

There is no general consensus by trade and development experts on the prevalence of the various potential downfalls of AfT and economic analyses show varying results demonstrating both gains and losses for recipient countries. The extent of gains and losses depends on the relationships between donors, recipient countries, and their individual aid and trade policies (Suwa-Eisenmann and Verdier 2007). To determine the value of AfT, the WTO should systematically evaluate if AfT initiatives achieve the overall intended goals set forth in the Doha Development Round despite the various economic effects that result across LDCs by answering this question: do LDCs benefit the most from AfT with clear reductions in poverty?

Stakeholders, including IGOs and government agencies involved with AfT programs, have asked the WTO to measure the extent to which AfT initiatives build LDCs' capacity to enhance trade flows, integrate into the global trading system, and reduce poverty levels. According to existing literature and the predictions of economic models, AfT results depend fully on the use of funds by each recipient country (Adam 2005). Therefore, when developing policy recommendations, no policy will unilaterally affect each LDC equally. Each recipient country must be monitored and evaluated to determine if AfT is benefiting the country economically and reducing poverty through predetermined measures tailored to each LDC.

Given the evidence that AfT has demonstrated positive economic development in many LDCs, it may seem counterproductive to argue against AfT policies as a whole. However, the purpose of AfT is not to create trade and private sector growth only for certain parties in developing countries and LDCs; AfT's primary purpose is to reduce overall poverty levels. So far, there is little evidence that current AfT initiatives achieve this goal in all LDCs and there is reason to believe that some recipient countries face even greater economic disparity from the trade liberalization created through AfT (Jomo and Von Arnim 2008). Ultimately, increased inequality prevents poverty reduction, which is counter to the goals of AfT (UNDP 2013).

While inequality may seem an inevitable side effect of trade liberalization based on analyses mentioned above, experts argue that many developing countries have been able to grow economically while reducing inequality in the process, citing Brazil as an example (UNDP 2013). Brazil, however, is not an LDC, and many national policies and programs unique to the country have enabled this coinciding growth and inequality reduction. Increased inequality in LDCs, especially as a result of AfT, should be viewed as a problem for future AfT initiatives to remedy through country-specific targeted packaging of programs and policy implementation that mitigates potential digressions from the overall goal.

\section{POTENTIAL POLICIES}

Traditional solutions to the negative effects of trade liberalization are referred to as protectionist measures, or policies designed to protect domestic workers, firms, and 
producers from foreign competitors (Wolla and Esenther 2017). While these measures protect some of the third parties hurt by AfT initiatives, such as small business owners, they may also reduce the net benefits of global trade by reducing overall trade volume (Wolla and Esenther 2017). Free market advocates tend to push for unregulated trade, but AfT is fundamentally based on the notion that certain cases of extreme poverty warrant government interference. Implementing specific protectionist measures while simultaneously engaging in AfT programs that promote trade liberalization should force recipient countries and donors to adjust policies to better support the LDCs and focus on poverty reduction. There are three particular measures that may reduce the unintended repercussions of AfT: tariffs, quotas, and subsidies.

First, increasing tariffs on foreign imported goods could provide an advantage to domestic firms that cannot yet compete with global pricing. Although tariffs naturally create a loss in overall market efficiency, if the purpose of AfT is to reduce poverty in LDCs, then creating multi-structured policy that benefits firms in LDCs, such as one that includes tariffs, should be of priority to administrators of AfT initiatives.

Second, imposing import quotas on foreign goods that are outcompeting domestic goods could improve current AfT trade policy. By imposing an import quota, the number of imported goods in the LDCs may not meet the country's consumer demand, creating an opportunity for domestic producers. Import quotas could give firms in LDCs temporary advantages over global firms when competing for consumers and provide LDCs the opportunity to grow domestic production. This temporary advantage, along with AfT programs, could create more sustainable economic outcomes for recipient countries while preventing the inequalities that can form through trade liberalization.

Third, while current AfT programs usually do not include subsidies, participating IGOs and government agencies could provide financial incentives like subsidies to lower overall production costs for domestic firms, helping to increase supply to meet unmet market demands resulting from the quota.

While the WTO, participating donors, and recipient countries already engage in combinations of policies and programs to fit specific recipient country needs, different challenges LDCs face due to trade liberalization require additional research and work to find the right balance of protectionism and liberalization to reduce inequality and facilitate growth.

The WTO has made efforts to evaluate and implement policies to improve AfT programs. Most notably, in 2006, the WTO implemented a Task Force to determine how to better operationalize AfT funding. The Task Force concluded that AfT's sustainable development goals need to be clarified, and that AfT initiatives need to adopt a gender perspective in each program to specifically evaluate negative impacts on women and ways to improve women's economic empowerment. While AfT may improve trade capacities and infrastructure, women in recipient countries continue to face barriers to entering the paid economy, receiving lower wages and fewer work opportunities compared with men (OECD and WTO 2019). In 2017, acting on the Task Force's conclusion, the WTO released a Joint Declaration on Trade and Women's Economic Empowerment acknowledging that AfT programs will also address improving gender equality through implementing genderresponsive trade policies and clarifying AfT's sustainable development goals (OECD 
and WTO 2019). By broadening the key goals of the AfT initiative to include a gender perspective, AfT programs may create more positive returns for women and their families. Through improving labor conditions, access to formal work, and pay, AfT programs could further assist in reducing poverty levels by closing the gender gap and improving health and education outcomes for women (OECD and WTO 2019).

The WTO is committed to monitoring and evaluating AfT on three levels: global monitoring carried out by the OECD, donor monitoring, and in-country monitoring (WTO 2019a). In 2019, evaluation of AfT was expanded to measure economic diversification within countries and economic empowerment, with a focus on women. The Task Force is scheduled to report on the progress of implementing a gender perspective in AfT policies in 2020 (OECD and WTO 2019). Through such evaluations, the WTO may learn how to effectively revise AfT programs to reduce inequalities created through trade liberalization and improve institutional capacities for delivery in recipient countries, while still promoting economic growth.

\section{CONCLUSION}

Least-developed countries (LDCs) face many barriers in the global market and the AfT initiative is designed to make them better off. Although the goal is to reduce global poverty levels, the economic benefits of AfT are not distributed fairly among participating countries. While positive economic growth can be seen in both developed and developing countries, the developed countries do not experience the same downfalls of international trade as the LDCs, such as negative domestic effects of trade liberalization, "Dutch disease," or problems with aid fungibility. Further, recipient countries, particularly LDCs, are vulnerable to increasing inequality resulting from trade liberalization. By finding a balance of protectionist and liberalization policies, implementing gender-sensitive policies, as well as ensuring a continued commitment from the WTO to improve how funds are dispensed, monitored, and evaluated, AfT programs may be better designed to ensure that recipient countries are the clear winners in global trade agreements. Though all countries may benefit from participating in global trading markets, the goal of all AfT programs should focus on enhancing the mission for which they were designed: alleviating poverty.

\section{REFERENCES}

Adam, Christopher. 2005. "Exogenous Inflows and Real Exchange Rates: Theoretical Quirk or Empirical Reality?" Paper presented at the seminar hosted by the International Monetary Fund (IMF) on Foreign Aid and Macroeconomic Management in Maputo, Mozambique, March 14-15, 200

Anderson, Kym, and Will Martin. 2005. "Agricultural Trade Reform and the Doha Development Agenda." In Agriculture, Trade Reform, and the Doha Development Agenda, edited by Kym Anderson and Will Martin. Washington, DC: The World Bank.

Bearce, David, H., Steven Finkel, Anibel Pérez-Liñán, Juan Rodríguez-Zepeda, and Lena SurzhkoHarned. 2013. "Has the New Aid for Trade Agenda been Export Effective? Evidence on the Impact of US AfT Allocations 1999-2008." International Studies Quarterly 57 (1): 163-170. https://dx.doi.org/10.1111/isqu.12027. 
Borgatti, Lisa. 2007. "Timing and Sequencing of Trade Liberalization in the Least-Developed Countries: Does Foreign Aid Play a Role?” Economia Internazionale 60 (1): 33-56.

Bouët, Antoine, Jean-Christophe Bureau, Yvan Decreux, and Sebastian Jean. 2005. "Multilateral Agricultural Trade Liberalization: The Contrasting Fortunes of Developing Countries in the Doha Round." IIIS Discussion Paper No. 60:1329-1354. http://dx.doi.org/10.2139/ssrn.739686.

Feyzioglu, Tarhan, Vinaya Swaroop, and Min Zhu. 1998. "A Panel Data Analysis of the Fungibility of Foreign Aid." World Bank Economic Review 12 (1): 29-58. http://documents.worldbank.org/ curated/en/514331468149391238/pdf/772610JRN0WBER0Box0377301B00PUBLIC0.pdf.

Gero, Anna. 2014. “Does 'aid for trade' really help reduce poverty?” The Conversation, June 23, 2014. https://theconversation.com/does-aid-for-trade-really-help-reduce-poverty-28194.

Gnangnon, Sena Kimm. 2018. "Aid for trade and trade policy in recipient countries." The International Trade Journal 32 (5): 439-464. http://dx.doi.org/10.1080/08853908.2018.1436478.

Hoekman, Bernard, and Marcelo Olarreaga. 2007. “The Challenges to Reducing Poverty through Trade Reform: Overview." In Global Trade and Poor Nations, edited by Bernard Hoekman and Marcelo Olarreaga, 11-30. Brookings Institution Press.

Jomo, K.S., and Rudigar Von Arnim. 2008. "Trade Liberalisation for Development? Who Gains? Who Loses?” Economic and Political Weekly 43 (48): 11-12.

OECD and WTO (Organization of Economic and Co-operative Development and World Trade Organization). 2019. "Aid for Trade at a Glance 2019: Economic Diversification and Empowerment.” Paris: OECD. https://doi.org/10.1787/18ea27d8-en.

Suwa-Eisenmann, Akiko, and Thierry Verdier. 2007. "Aid and trade." Oxford Review of Economic Policy 23 (3): 481-507. http://dx.doi.org/10.1093/oxrep/grm028.

UN (United Nations). 2019. “LDC Identification Criteria \& Indicators.” Economic Analysis \& Policy Division. Accessed March 4, 2020. https://www.un.org/development/desa/dpad/leastdeveloped-country-category/ldc-criteria.html.

UNDP (United Nations Development Programme). 2013. "Humanity Divided: Confronting Inequality in Developing Countries.” Accessed May 2, 2019. https://www.undp.org/content/undp/en/home/ librarypage/poverty-reduction/humanity-divided--confronting-inequality-in-developingcountries.html.

Wolla, Scott, and Anna Esenther. 2017. "Does International Trade Create Winners and Losers?" Page One Economics, November 2017. https://research.stlouisfed.org/publications/page1econ/2017/11/01/does-international-trade-create-winners-and-losers/.

WTO (World Trade Organization). 2017. “Trade, inclusiveness and connectivity." Aid for Trade Global Review. Video File, 3:42. June 24, 2017. https://www.wto.org/english/tratop_e/devel_e/a4t_e/ gr17_e/video_e.htm\#webcasting_video.

WTO (World Trade Organization). 2019a. "Aid for Trade" Last modified October 2019. https://www.wto. org/english/tratop_e/devel_e/a4t_e/aid4trade_e.htm.

WTO (World Trade Organization). 2019b. "Least-developed Countries." Accessed November 29, 2019. https://www.wto.org/english/thewto_e/whatis_e/tif_e/org7_e.htm.

WTO (World Trade Organization). n.d. Understanding the WTO: Developing Countries. Accessed November 29, 2019. https://www.wto.org/english/thewto_e/whatis_e/tif_e/dev1_e.htm. 
TIMOTHY WOLF BARHAM is a second-year Master of Public Policy (MPP) candidate at the Trachtenberg School, concentrating on publicprivate policy and the interactions between business and government. Born in Oklahoma and raised in Colorado, Timothy graduated summa cum laude from the University of Colorado at Boulder studying Classics with a focus on philology, ancient history, and law. Before graduate school, Timothy committed three years to the non-profit sector, leading humanitarian projects both domestically and globally in Papua New Guinea, India, Haiti, Ireland, and Mexico.

\section{ACKNOWLEDGEMENTS}

The author would first like to thank his parents, Kenny and JoAnn, who always support his education and interests through their own love and sacrifice. He thanks Professor Kathryn Newcomer for her thoughtful insights and guidance through his first published paper. For her watchful eye, careful editing, and tireless efforts, he thanks Katie Howell, his Policy Perspectives Associate Editor, for her invaluable contributions to this paper. He thanks Kendall Banks, the Policy Perspectives Editor-in-Chief, for her numerous edits and helpful feedback. Finally, he thanks Julie, his better half, for her ever-constant support and encouragement, without which this paper would not have been possible. 